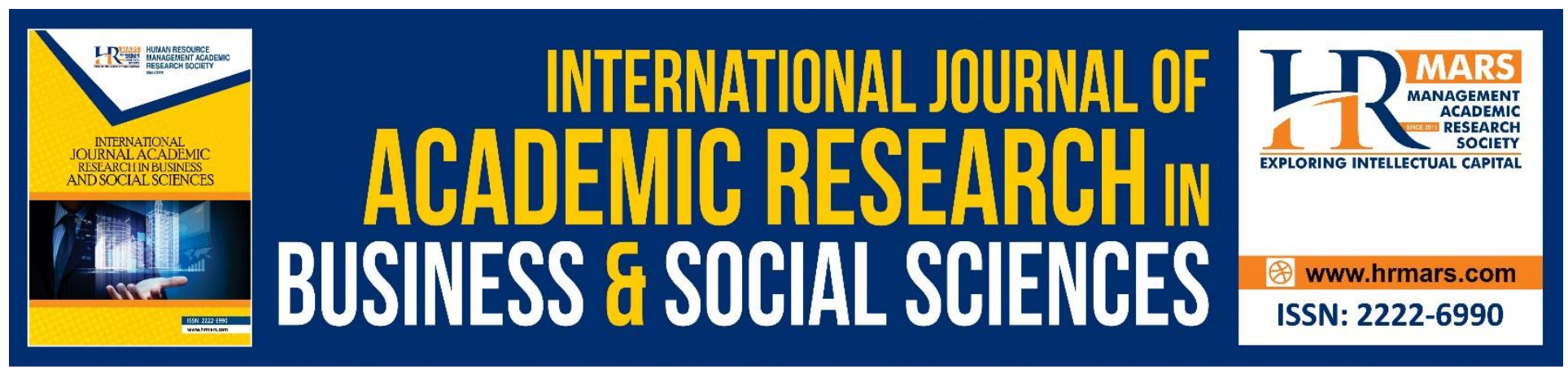

\title{
The Effectiveness of Online Distance Learning (ODL) Approach in University: A Respond of Covid-19 Pandemic Crisis
}

\author{
Aini Hayati Musa, Alia Nadira Rosle, Farrah Nadia Baharuddin, Siti Sara \\ Ibrahim
}

To Link this Article: http://dx.doi.org/10.6007/IJARBSS/v10-i9/7986

DOI:10.6007/IJARBSS/v10-i9/7986

Received: 23 July 2020, Revised: 15 August 2020, Accepted: 02 September 2020

Published Online: 26 September 2020

In-Text Citation: (Musa, Rosle, Baharuddin, \& Ibrahim, 2020)

To Cite this Article: Musa, A. H., Rosle, A. N., Baharuddin, F. N., \& Ibrahim, S. S. (2020). The Effectiveness of Online Distance Learning (ODL) Approach in University: A Respond of Covid-19 Pandemic Crisis. International Journal of Academic Research in Business and Social Sciences. 10(9), 1069-1076.

Copyright: (C) 2020 The Author(s)

Published by Human Resource Management Academic Research Society (www.hrmars.com)

This article is published under the Creative Commons Attribution (CC BY 4.0) license. Anyone may reproduce, distribute, translate and create derivative works of this article (for both commercial and non-commercial purposes), subject to full attribution to the original publication and authors. The full terms of this license may be seen

at: http://creativecommons.org/licences/by/4.0/legalcode

\section{Vol. 10, No. 9, 2020, Pg. 1069 - 1076}




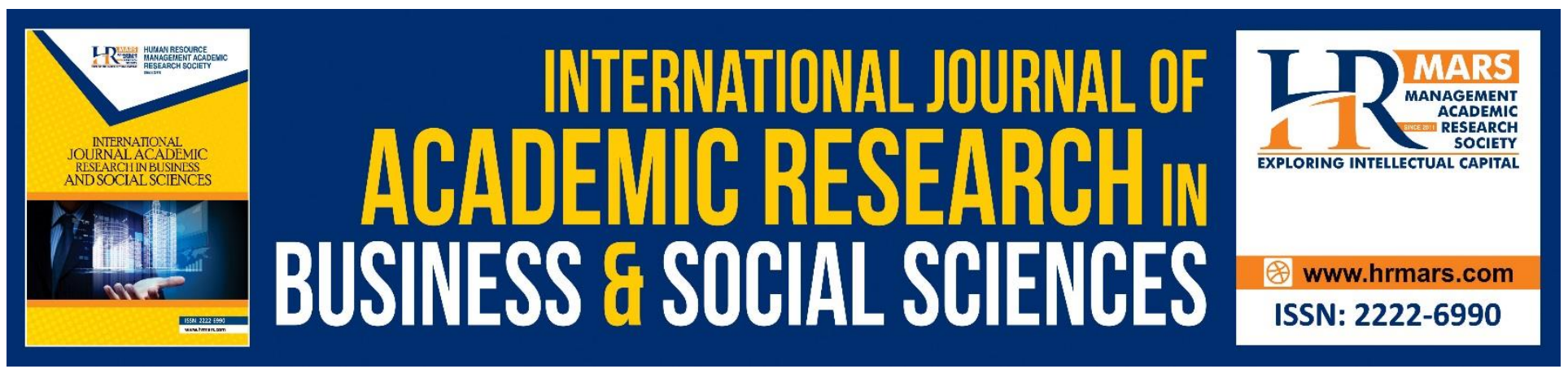

\title{
The Effectiveness of Online Distance Learning (ODL) Approach in University: A Respond of Covid-19 Pandemic Crisis
}

\author{
Aini Hayati Musa ${ }^{1}$, Alia Nadira Rosle ${ }^{2}$, Farrah Nadia Baharuddin¹, \\ Siti Sara Ibrahim ${ }^{1}$ \\ ${ }^{1}$ Faculty of Business and Management, Universiti Teknologi MARA (UiTM), Malaysia, ${ }^{2}$ Faculty of \\ Computer Science and Mathematics, Universiti Teknologi MARA (UiTM), Malaysia
}

\begin{abstract}
The COVID-19 pandemic has proved one of the most devastating health crises of the 21st century. Due to this reason, many educational institutions were closed in order to save lives. This action can cause interruption in educational activities. Due to this issue, Online Distance Learning (ODL) have grown in popularity and is seen as an alternative method in higher educational setting. We are now moving towards a new normal life practices due to this global health crisis. Adapting to this new normal, Universiti Teknologi MARA (UTTM) continue their teaching and learning activities using Online Distance Learning (ODL) approach starting from 13 April 2020 until now. This research paper is conducted to conceptually propose the effective strategy to conduct online distance learning (ODL) in UiTM through the perspective of ODL interaction, motivation, students' performance and ICT and technology support system. This is due to the concern that going digital effectively requires substantial coordination by management and support from ICT service providers. Thus in order to develop ODL effectively, we must see our readiness to use an effective ODL approach as well as needs for robust curriculum pedagogical and methods. Educators must also know the students condition such as their motivation and ability to have good internet connection so that ODL can allows students to access lessons and interact with educators.
\end{abstract}

Keywords: Online Distance Learning, Motivation, Student Performance, Information and Communication Technology

\section{Introduction}

The implementation of Movement Control Order (MCO) starting 18 March 2020 until now. MCO is a preventive action implemented by the federal government of Malaysia in response to the COVID-19 pandemic in the country. The purpose of the MCO is to break the chain of transmission with the ultimate aim of levelling the rate of infection, meaning it will no longer be exponential. Responding to this pandemic, Universiti Teknologi MARA (UiTM) is taking an effort to continue its learning activities by using online distance learning (ODL) approach. Educators need to conduct their teaching 
INTERNATIONAL JOURNAL OF ACADEMIC RESEARCH IN BUSINESS AND SOCIAL SCIENCES Vol. 10, No. 9, 2020, E-ISSN: 2222-6990 @ 2020 HRMARS

and learning activities via online methods from home. They work from home. Among online methods used in ODL approach are Whatsapp, Telegram, Google Meet, Hangout, Google Classroom, Ilearn and Ufuture. Using variety of online platforms can suit the needs of the students.

Alseweed (2013) highlighted that e-learning has been introduced to facilitate traditional teachinglearning processes, and it encompasses the use of electronic devices such as computers, mobile phones or tablets to provide online learning materials. Due to increased recognition of social interaction in professional learning, a key theme of recent literature has been highlighted on how technology can promote the cognitive processes in knowledge construction among teachers (Zhang et al., 2017). In addition, the ability of the learners, their computer competency and experience and their attitudes toward particular technologies are among the significant factors found in many previous studies related to the adoption of educational technology (John, 2015; Surej, 2015; Tran and Glowatz, 2014). Dumford and Miller (2018) also highlight how the use of online assessments might adversely affect the opportunities provided for students to receive formative feedback.

One reason why there is so much discussion around online learning is that there are many purported benefits and uses of online learning. Some of the most important ones are: its effectiveness in educating students, its use as professional development, its cost-effectiveness to combat the rising cost of postsecondary education, credit equivalency at the postsecondary level, and the possibility of providing a world class education to anyone with a broadband connection (Bartley \& Golek, 2004; De la Varre, Keane, \& Irvin, 2011; Gratton-Lavoie \& Stanley, 2009; Koller \& Ng, 2014; Lorenzetti, 2013).

However, developments in learning technology have challenged higher education (HE) institutions to change how they design and deliver their programs. By creating an environment in which students feel comfortable with the idea of technology-based learning, universities can facilitate the development of a skillset that will enable graduates to continue to develop throughout their careers (Chartered Institute of Personnel and Development (CIPD, 2017). Thus, effectiveness is the main concern for most of the organization in realizing their goals and achievements. This study is done to conceptually propose the effective strategy to conduct online distance learning (ODL) in UiTM through the perspective of ODL interaction, motivation, students' performance and ICT and technology support system.

\section{Literature Review}

Effectiveness is the main concern for most of the organization in realizing their goals and achievements. Nevertheless, higher learning institutions are also do not miss the importance of efficiency of conducting online distance learning (ODL) during the Covid 19 pandemic. It is also known that the institutional and administrative effectiveness and productivity of ODL are critical to the determination of student progress, retention and results.

\section{Interaction of ODL}

Interactivity has a lot of different dimensions (Murphy et al., 2001). A few authors has discussed the needs of interaction in ODL (Anderson, 2003; Boyle \& Wambach, 2001; Dzakiria, 2004, 2008; Muirhead, 2001). According to Tait (2000), in the instructional theory, interaction provides the means for students to receive feedback. Due to this, as feedback determines a positive development 
INTERNATIONAL JOURNAL OF ACADEMIC RESEARCH IN BUSINESS AND SOCIAL SCIENCES Vol. 10, No. 9, 2020, E-ISSN: 2222-6990 @ 2020 HRMARS

in learning, it can be argued that the more interaction created, the better it would be for the students, the learning and also the teaching process. Dzakiria, (2012) stated that in ODL process, there are three types of interaction that are essential:

i. Learner-learner interaction

The learner-learner interaction can be described as interaction between one student and another or between several learners. The author mentioned that participation, response and feedback are necessary elements in order to make sure the ODL process is effective.

ii. Learner-tutor interaction and

The learner-tutor interaction takes place between the learners and tutors of the course is intended to help to enhance the learner's understanding of the course material and contents.

iii. Learner-interface interaction

The learner-interface interactions included computer skills, ICT expertise, easy access of technology and many mores. For example, lack of familiarity with the technology has been cited as a negative barrier to teach (Moore \& Kearsley, 2012).

\section{Motivation}

Motivation is one of important element in all forms of education especially in ODL since in ODL students are alone in their teaching and learning process. There are two fundamental types of motivation that are intrinsic and extrinsic. Intrinsic motivation indicates individual's internal motivation such as student's driving force in teach a subject itself. Meanwhile, extrinsic is external motivation received from external parties such as praise from the teacher for the good work (Ryan \& Deci, 2000).

In 1979, John Keller has proposed a theory of motivation and also a model with given name as Keller's ARCS. This model is designated to incorporate motivation in instruction where basically this theory explained on motivation fundamental (Devisakti, 2016).

\section{Student Performance}

Another way to measure the effectiveness of ODL is through the students' performance. Students' performances are the major concern in an education system whereby theirs performance act as indicator level of education institution achievement. Oliver and Tigwell (2005), claimed that blended learning has increases student performance. However, the successful implementation of blended leaning in one institution does not guarantee the effectiveness of the strategy at another institution.

\section{Information and Communication Technology (ICT) and Technology Support System}

ICT and technology support system plays an essential role in ODL. In ODL system it is a requirement to have a good ICT and technology support system since it is difficult to conduct learning process using traditional method in ODL. Various types of technologies and media are used in open and distance education to transfer education to learners. Rumble (1995) mentioned there are four media namely print, audio, television computer are available for teaching purposes, in one technological form or another. 
INTERNATIONAL JOURNAL OF ACADEMIC RESEARCH IN BUSINESS AND SOCIAL SCIENCES Vol. 10, No. 9, 2020, E-ISSN: 2222-6990 @ 2020 HRMARS

Rahman (2014) stated that technological advancements, especially in the field of ICT, allow teachers to use different strategies that could actively engage students ' interests. Open distance learning system requires ICT infrastructure to provide a variety of services effectively which includes a network Infrastructure, computer infrastructure, system and application software, the Internet Service Provider(ISP), bandwidth, policy framework and safety infrastructure (Rao, Murali, 2010).

\section{Discussion}

This study was designed to construct the effectiveness of online distance learning in university during Covid19 for both educators and students that can be proposed. The effectiveness of the online distance learning (ODL) for the study are as follows

\section{Interaction of Online Distance Learning}

For interaction of online distance learning, the study proposes to look into three areas such as learner-learner interaction, learner-tutor interaction as well as learner-interface interaction. Thus, it consistent with the study that online distance learning always using learner-learner interaction as a medium of boost online learning (Tawfik et al., 2017). Moreover, previous studies also suggest that the effectiveness of positive online learning outcomes based on the online learning environments that support the interaction between learner-learner, learner-tutor as well as learner-interface interaction among students (Cecilia et al., 2015; Zimmerman, 2012).

\section{Motivation}

Motivation is one of the importance elements in reaching effectiveness of online distance learning. The previous studies mentioned that intrinsic motivation as the vital elements of online distance learner (Shroff et al., 2007) and the characteristics of online distance students should have high intrinsic motivation, self-direction and independence (Moore, 1989). It is notable that several studies have explored the relationship between intrinsic-extrinsic motivation and the students' engagement in online learning (Rentroia-Bonito et al., 2006; Shroff \& Vogel, 2009; Xie \& Ferguson, 2006).

\section{Student Performance}

It is notable that several factors will enhance students' performance among online learners (Stansfield et al., 2004). The said factors such as self-sufficient learners, flexibility of access of learning materials, experienced learners studying strategically, learner control over the pace of study as well as assessments aimed at developing greater learner reflection. Moreover, the study on students' performance on online distance learning shown that attitude and readiness have positively influenced the students' performances on the implementation of online learning system (Humaidi et al., 2013)

\section{Information and Communication Technology (ICT) and Technology Support System}

ICT and technology support system play an importance role in creating effectiveness on online distance learning. Open and distance learning has dependent toward ICT and communication technology, and it has been playing an important role in the delivery strategies of distance learning (Rahman, 2014). By having the advancement in technology has introduces diversities of new ways for educators as well as learner to increase knowledge in education. Further, open distance learning 
INTERNATIONAL JOURNAL OF ACADEMIC RESEARCH IN BUSINESS AND SOCIAL SCIENCES Vol. 10, No. 9, 2020, E-ISSN: 2222-6990 @ 2020 HRMARS

system requires ICT infrastructure to provide a variety of services effectively which includes a network infrastructure, computer infrastructure, system and application software, the Internet Service Provider(ISP), bandwidth, policy framework and safety infrastructure (Rao, 2010).

\section{Conclusion}

Online Distance Learning (ODL) have grown in popularity due to pandemic COVID-19. This application is seen as an alternative method in higher educational setting in Malaysia. We are now moving towards a new normal life practices due to this global health crisis. ODL can be conducted on various way such as video conferencing, synchronous and asynchronous, open online course, hybrid distance education, computer based, fixed time online course and many more. However, developments in learning technology have challenged the university to change how they design and deliver their programs. By creating an environment in which students feel comfortable with the idea of technology-based learning, universities can facilitate the development of a skillset that will enable graduates to continue to develop throughout their careers. Thus, effectiveness is the main concern for most of the organization in realizing their goals and achievements.

For interaction of online distance learning, the study proposes to look into three areas such as learner-learner interaction, learner-tutor interaction as well as learner-interface interaction. Meanwhile motivation is one of the importance elements in reaching effectiveness of online distance learning in which finally lead to student's performance. Finally by having the advancement in technology has introduces diversities of new ways for educators as well as learner to increase knowledge in the educational journey. Thus the study is proposed to focuses on the following variables to effectively implement online distance learning (ODL) in Universiti Teknologi MARA namely, interaction of online distance learning, motivation, students' performance as well as information and communication technology (ICT) also technology support system. However, the limitation in this study is also proposed to be conducted in future study in which empirically assess the variables so that it can consistently supports the conceptual proposed of the current study.

\section{References}

Alseweed, M. A. (2013). Students' achievement and attitudes toward using traditional learning, blended learning, and virtual classes learning in teaching and learning at the university level. Canadian Academy of Oriental and Occidental Culture, Studies in Literature and Language, 6(1), 65-73.

Anderson, T. (2003). Getting the mix right again: An updated and theoretical rationale for interaction. International Review of Research in Open and Distance Learning, 4(2), 1-14.

Bartley, S. J., \& Golek, J. H. (2004). Evaluating the Cost Effectiveness of Online and Face-to-Face Instruction. Educational Technology \& Society, 7(4), 167-175.

Boyle, D. K., and Wambach, K. A. (2001). Interaction in graduate nursing Web-based instruction. Journal of Professional Nursing, 17, 128-134.

Cecilia, B., Rodriguez, P., \& Armellini, A. (2015). Expanding the Interaction Equivalency Theorem. The International Review of Research in Open and Distributed Learning, 16(3), 298-317.

Chartered Institute of Personnel and Development (CIPD) (2017), The Future of Technology and Learning, available at: https://www.cipd.co.uk/Images/the-future-of-technology-andlearning_2017_tcm18-29348.pdf (accessed 20 May 2020). 
INTERNATIONAL JOURNAL OF ACADEMIC RESEARCH IN BUSINESS AND SOCIAL SCIENCES Vol. 10, No. 9, 2020, E-ISSN: 2222-6990 @ 2020 HRMARS

De la Varre, C., Keane, J., \& Irvin, M. J. (2011). Enhancing Online Distance Education in Small Rural US Schools: A Hybrid, Learner-Centred Model. Journal of Asynchronous Learning Networks, 15(4), 35-46.

Devisakti, A. (2016). Institutional Factors that Motivates Adult Learners in ODL. Asean Journal of Open and Distance Learning, 8(2), 67-76.

Dumford, A., and Miller, A. (2018), "Online learning in higher education: exploring advantages and disadvantages for engagement", Journal of Computing in Higher Education, 30(3), 452-465.

Dzakiria, H., and Walker, R. (2003). Understanding the Culturally Diverse - Malaysian Distance Learners: Does Culture has a Role and an Effect on Learning and Practice in Distance Education. Malaysian Journal of Distance Education, 5(1), 95-107.

Dzakiria, H., and Idrus, R. M. (2003). Teacher-Learner Interactions in Distance Education: A Case of Two Malaysian Universities. Turkey On-line Journal of Distance Education (TOJDE), 4(30).

Dzakiria, H., and Walker, R. (2012). Illuminating the Importance of Learning Interaction to Oprn Distance Learning Success: A Qualitative Perspective of Adult Learners in Perlis Malaysia. European Journal of Open, Distance and E-Learning.

Gratton-Lavoie, C., \& Stanley, D. (2009). Teaching and learning principles of Microeconomics online: An empirical assessment. The Journal of Economic Education, 40(1), 3-25.

Humaidi, N., Mohd, M. S., Azilah, N., Asarani, M., \& Annuar, A. (2013). Students' Performance on the Implementation of Online Learning System.

John, W. (2015). Chapter 16 leadership in implementing technology-enhanced learning in educational institutions, E-Learning - instructional design. Organizational Strategy and Management, 393412.

Lorenzetti, J. (2013.). Academic Administration - Running a MOOC: Secrets of the World's Largest Distance Education Classes - Magna Publications.

Moore, M. G. (1989). Three Types of Interaction. American Journal of Distance Education, 3(2), 1-7.

Muirhead, B. (2001). Enhancing social interaction in computer-mediated open distance learning. USDLA Journal, 15(4). Retrieved January 4, 2004, from http://www.usdla.org/html/journal /APR01_Issue/article02.html.

Murphy, D., Walker, R., \& Webb, G. (2001). Online Learning and Teaching with Technology: Case Studies, Experience and Practice. London: Kogan Page Limited.

Nguyen, T. (2015). The Effectiveness of Online Learning: Beyond No Significant Difference and Future Horizons. MERLOT Journal of Online Learning and Teaching, 11(2), 309 - 319.

Oliver, M., \& Tigwell, K. (2005). Can blended learning be redeemed? E-learning. 2(1), 17-26.

Rahman, H. (2014). The role of ICT in open and distance education. Turkish Online Journal of Distance Education, 15(4), 162-169.

Rao, A., Murali, M. (2010). ICT in Open Distance Learning: Issue and Challenges. Pan-Commonwealth Forum.

Rentroia-Bonito, M., Jorge, J., \& Ghaoui, C. (2006). Motivation to E-Learn Within Organizational Settings. Journal of Distance Education Technologies, 4(3), 77-89.

Rumble, G. (1995). Media use at Open University, The Guardian, (Dhaka, Bangladesh) Bangladesh Open University.

Ryan, R. M., and Deci, E. L. (2000). Intrinsic and extrinsic motivations: Classic definitions and new directions. Contemporary Educational Psychology, 25, 54-6. 
INTERNATIONAL JOURNAL OF ACADEMIC RESEARCH IN BUSINESS AND SOCIAL SCIENCES

Vol. 10, No. 9, 2020, E-ISSN: 2222-6990 @ 2020 HRMARS

Shroff, R. H., \& Vogel, D. R. (2009). Assessing the Factors Deemed to Support Individual Student Intrinsic Motivation in Technology Supported Online and Face-to-Face Discussions. 8.

Shroff, R. H., Vogel, D. R., Coombes, J., Lee, F., \& Vogel, D. (2007). Student E-Learning Intrinsic Motivation: A Qualitative Analysis. 19(March).

Stansfield, M., Mclellan, E., \& Connolly, T. (2004). Enhancing Student Performance in Online Learning and Traditional Face-to-Face Class Delivery. Journal of Information Technology Education, 3.

Surej, P. J. (2015). The integration of information technology in higher education: a study of faculty's attitude towards IT adoption in the teaching process. Contaduría y Administracion.

Tait, A. (2000). Planning student support for open and distance teaching. Open Learning, 15(3), 287299.

Tawfik, A. A., Reeves, T. D., Stich, A. E., Gill, A., Hong, C., Mcdade, J., \& Sai, V. (2017). The nature and level of learner - learner interaction in a chemistry massive open online course (MOOC). Journal of Computing in Higher Education, 29, 411-431.

Tran, T., and Glowatz, M. (2014). A comparative case study of Irish and Vietnamese students' eLearning perceptions and acceptance. Proceedings of the 16th International Conference on Information Integration and Web-based Applications and Services (iiWAS '14), 44-48.

Xie, K. U. I., \& Ferguson, C. (2006). Extending te traditional classroom through online discussion: The role of student motivation. 34(1), 67-89.

Zhang, S., Liu, Q., Chen, W., Wang, Q., and Huang, Z. (2017). Interactive networks and social knowledge construction behavioural patterns in primary school teachers' online collaborative learning activities. Computers and Education, 104, 1-17.

Zimmerman, T. D. (2012). Exploring Learner to Content Interaction as a Success Factor in Online Courses. The International Review of Research in Open and Distributed Learning, 13(4), 152-165. 